\title{
PSYCHOSOCIAL CORRELATES OF HEALTH PRACTICES IN BLACK SOUTH AFRICAN UNIVERSITY STUDENTS
}

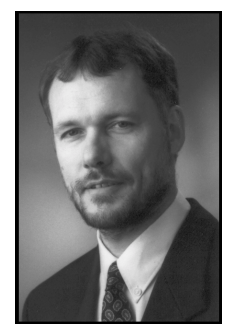

\author{
Prof. Karl Peltzer \\ Department of Psychology \\ University of the North
}

\section{OPSOMMING}

Die doel van die navorsing was om die voorkeur en die korrelasies van psigososiale gesondheidspraktyke van jong manlike en vroulike volwassenes te bestudeer. Die steekproef bestaan uit 793 studente van die Universiteit van die Noorde in Suid-Afrika wat nie geregistreer is vir kursusse in die gesondheidswetenskappe nie. Die studente is ewekansig toegewys. Van die studente was 370 mans (46.7\%) en 423 (53.4\%) dames. Almal was in die ouderdomsgroep van 18 tot 25 jaar (Gemiddelde ouderdom $=21.0$ en standaardafwyking =3.48). Die metingsinstrumente het die volgende ingesluit: "Health Practice Index, Health Locus of Control Scale, Health as a value Scale, Subjective health Status, Subjective well-being, Health benefits, Health Status”. Die resultate dui daarop dat die studente se gesondheidsgedrag uit 'n totaal van 14 bogemiddeld bo 7 meet. Daar was 'n beduidende verskil tussen die geslagte in die resultate van die "Health Practice Index". Die dames se gedrag was gemiddeld gesonder as die van die mans in terme van tabakgebruik, alkoholinname, gebruik van sitplekgordels en selfondersoek vir kanker. Mans het meer gereeld as dames aan oefening deelgeneem. Meer as 70\% van die studente het die volgende gesondheidspraktyke nagekom: tande borsel een of meer keer per dag, nie gebruik van tabak, geen alkoholgebruik of ongereelde alkoholinname, beperkte gebruik van rou rooivleis, en geen deelname aan sonbad nie. Formele opvoeding deur die moeder, interne lokus van kontrole en swak gesondheid is positief verbind met die "Health Practice Index". Ander sosiodemografiese faktore soos ouderdom, godsdiens asook sielkundige faktore soos "health values, health benefits" was nie beduidend verbind met gesondheidspraktyke nie.

\section{ABSTRACT}

The purpose of this study was to assess the prevalence and psychosocial correlates of health practices among young male and female adults. The sample included 793 Black University students from non-health courses chosen at random from the University of the North, South Africa. The students were 370 (46.7\%) males and $423(53.3 \%)$ females in the age range of 18 to 25 years ( $M$ age $=21.0$ years, $S D=3.48$ ). The assessment measures included a Health Practices Index, the Health Locus of Control Scale, Health as a Value Scale, subjective health status, subjective well-being, health benefits, and health status. Results indicated that participants practiced on average above 7 healthy behaviours from a total of 14. There was a significant sex difference in the health practices index, since on average the women's behaviour was more healthy than that of men in terms of tobacco use, alcohol consumption, seat belt use, and cancer selfexamination, but men exercised more regularly than women. Above $70 \%$ of the participants practiced the following health behaviours: brushing teeth once or more per day, non-tobacco use, very occasional or no alcohol, limited red meat, and never sunbathed or used suncreen in that order. Formal education of the mother, internal locus of control and worse health status were positively associated with the health practices index. Other sociodemographic (age, SES, religion) and psychological (health value, health benefits) factors were not significantly related to healthy practices. 


\section{INTRODUCTION}

Death postponing medical technology is resulting in increased rates of chronic non-communicable disorders as well as diseases of modern life in African populations (Peltzer, 1995:20). In regard to behavioural factors affecting physical conditions major disorders identified in South Africa are cardiovascular disorders, diabetes mellitus, life style related cancers, tobacco addiction, etc. In South Africa about $40 \%$ of people in the economically active age group (25-64 years) die because of chronic diseases (Bradshaw, Bourne, Schneider \& Sayed 1995: 7ff.). Principal causes of premature mortality in South Africa are increasingly cancer, heart disease, and strokes. Hypertension has a high prevalence in all language groups in South Africa (Edwards, 1992:105), in a black community in the Cape (9.2\% males and $12.9 \%$ females) (Steyn, Fourie, Lombard, Katzenellenbogen, Bourne \& Jooste, 1996:758), among urban Zulus 25\% and rural Zulus 9.4\% (Seedat, Seedat \& Hackland, 1982:256); 44\% of female black (Indian 22\%, Whites 18\%) South Africans are obese (Walker, 1995:73f.); 0.5 million South Africans suffer from diabetes (Levitt, Zwarenstein, Doepfmer, Bawa, Katzenellenbogen \& Bradshaw, 1996:1014). Yach (1996:29) reports that tobacco use among Blacks is rising in South Africa. For the country as a whole, lung cancer already accounts for $24 \%$ of all death from cancer in men, and $10.6 \%$ of all such death in women. In addition, there are high rates of road traffic accidents causing premature death and disability in South Africa (Forjuoh, Zwi \& Mock, 1998).

While the full aetiology of any of these diseases has yet to be understood, behavioural factors such as tobacco use, exercise, diet, alcohol consumption and preventive health checks are strongly implicated as risk factors (Steptoe \& Wardle, 1992:485f.). Steptoe, Wardle, Vinck, Tuomisto, Holte \& Wichstrøm (1994:331) note that health behaviours are activities undertaken by people in order to protect, promote or maintain health, and to prevent disease. The question of whether or not a "healthy lifestyle" can be identified is of major concern for health researchers and practitioners. A healthy lifestyle implies consistent health-conscious behaviour across a range of activities including dietary choice, substance use, exercise and preventive practices. Fourteen health behaviours were assessed and collated into a health practices index. The classification of responses as healthy or unhealthy was based on the literature relating behaviour to health risk. For example, any cigarette smoking was designated a negative health practice. In addition, no attempt was made to classify people as consistently healthy, consistently unhealthy or intermediate in their lifestyles. The number of health practices was analysed as a continuous variable with possible scores ranging from 0 (extremely unhealthy behaviour) to 14 (extreme health conscious-behaviour) (Steptoe et al. 1994:333f.).

The purpose of this study was to assess the prevalence of health practices among black South African university students. The first aim of this analysis was to identify the shape of the distribution of the health practices index. The second aim of this analysis was to investigate the socio-demographic and the psychosocial correlates (locus of control, health as a value, health benefits, health status, subjective well-being and subjective health) of healthconscious and unhealthy practices.

\section{METHODS}

\section{Sample and procedure}

The sample included 793 Black University students from non-health courses chosen at random from the University of the North, South Africa. The students were 370 (46.7\%) males and 423 (53.3\%) females in the age range of 18 to 25 years ( $M$ age 21.0 years, $S D=3.48$ ). 
Data were collected by a self-administered questionnaire in a class room situation after informed consent had been obtained. Participants were assured of complete anonymity.

\section{Measures}

The Health Practices Index included 14 positive health practices. It was constructed by giving a score of 1 for each of 14 positive health practices and a score of 0 when the practice was not carried out (Steptoe et al. 1994:334f.) (See Table 1).

Data were also collected by using additional instruments that assess factors established as important to health behaviour in research in health psychology. These included the Multidimensional Health Locus of Control Scale (MHLOC) (Wallston, Wallston \& De Villis, 1978), and the Health as a Value Scale (Lau \& Ware, 1981).

Attitudes toward health benefits were recorded by asking participants to rate the importance of a series of behaviours for health maintenance on 10point scales, where $1=$ low importance and $10=$ very great importance to health. Four items were included in this analysis: beliefs in not eating too much fat, taking regular exercise, not smoking, and not drinking too much alcohol.

Health status was assessed by asking participants whether they suffered from any health problems that had led to treatment from a doctor or health clinic over the past month, and whether they had used prescribed or unprescribed (over the counter) medications over the past month. The three measures of health status were included in a binary Yes/ No format (scored from 0 to 3) (Steptoe \& Wardle, 1992:487).

Additional measures included one item on subjective health status (rated from $1=$ excellent to $5=$ =poor), one question on subjective well-being (rated from $1=$ very satisfied to $5=$ very dissatisfied, and 6 items on sociobiographic data: age, sex, religion, income, car ownership in family, education of mother and father).

\section{RESULTS}

Table 1 summarises the frequency in percent for the health practices index for men and women (see Table 1).

Table 1: Health Practices Index by frequency in percent and by gender

\begin{tabular}{|c|c|c|c|}
\hline Healthy behaviour & $\begin{array}{l}\text { Men } \\
(\%)\end{array}$ & \begin{tabular}{|l} 
Women \\
$(\%)$
\end{tabular} & Chi-square \\
\hline 1. Non-tobacco use & 73 & 96 & 78.381 \\
\hline $\begin{array}{l}\text { 2. Alcohol consumption: very occasional or non- } \\
\text { drinker }\end{array}$ & 72 & 94 & $75.093^{* \ldots}$ \\
\hline 3. Physical exercise in past 2 weeks & 58 & 39 & $29.057^{\star \ldots 1}$ \\
\hline 4. Sleep time ( 7 to 8 hours) & 53 & 56 & .789 \\
\hline 5. Never sunbathes or uses sunscreen & 71 & 72 & 1.086 \\
\hline 6. Brushes teeth once or more per day & 97 & 98 & .751 \\
\hline 7. Eats red meat every $2-3$ days or less & 81 & 79 & 2.030 \\
\hline $\begin{array}{l}\text { 8. Makes a conscious effort to avoid eating foods } \\
\text { that contain fat and cholesterol }\end{array}$ & 37 & 51 & 15.712 \\
\hline 9. Less than usually add salt to meal & 46 & 47 & 422 \\
\hline 10. Fruits at least once a day & 24 & 34 & 16.196 \\
\hline 11. Breakfast almost every day & 50 & 51 & .307 \\
\hline 12. No between-meal snacks & 26 & 13 & 20.369 \\
\hline $\begin{array}{l}\text { 13. Always wearing a seat belt when driving or } \\
\text { sitting in the front seat of a car }\end{array}$ & 34 & 44 & $9.955^{\#-1}$ \\
\hline Total mean score & 7.2 & 7.8 & (t) $-4.388^{+\ldots t}$ \\
\hline $\begin{array}{l}\text { 14. Breast and testicle self-examination: for men, } \\
\text { checking testicles for lumps at least ten times a } \\
\text { year; for women, examining breasts for lumps at } \\
\text { least ten times a year }\end{array}$ & 0 & 25 & \\
\hline
\end{tabular}

University students practiced on average above 7 healthy behaviours from a total of 14 . There was a significant sex difference in the health practices index, since on average the women's behaviour was more healthy than that of men $(t=-4.388 ; \mathrm{p}<.001)$. Women practiced more non-tobacco use, non or very occasional drinking, avoided fat and used seat belts more often than men did. While $25 \%$ of the women examined breats for lumps at least ten times a year, none of the men checked their testicles for lumps at least ten times a year. Some men did test but less frequently and thus not qualifying for a healthy practice. Men did more often physical exercise and had less between-meal snacks than women did. Above $70 \%$ of the participants practiced the following health behaviours: brushing teeth once or more per day, non-tobacco use, very occasional or no alcohol, limited red meat, and never sunbathed or used sunscreen in that order. Almost one quarter (23.1\%) indicated that they used 
sun protection, sunscreen cream or lotion. The least (less than 40\%) health behaviours practiced by the students were: breast or testicle self-examination, no between-meal snacks, fruits at least once a day and always wearing a seat belt in that order.

The distribution of the health practices index is shown in Figure 1.

\section{Figure 1: Distribution of the Health Practices Index (from 0 to 14)}

health index

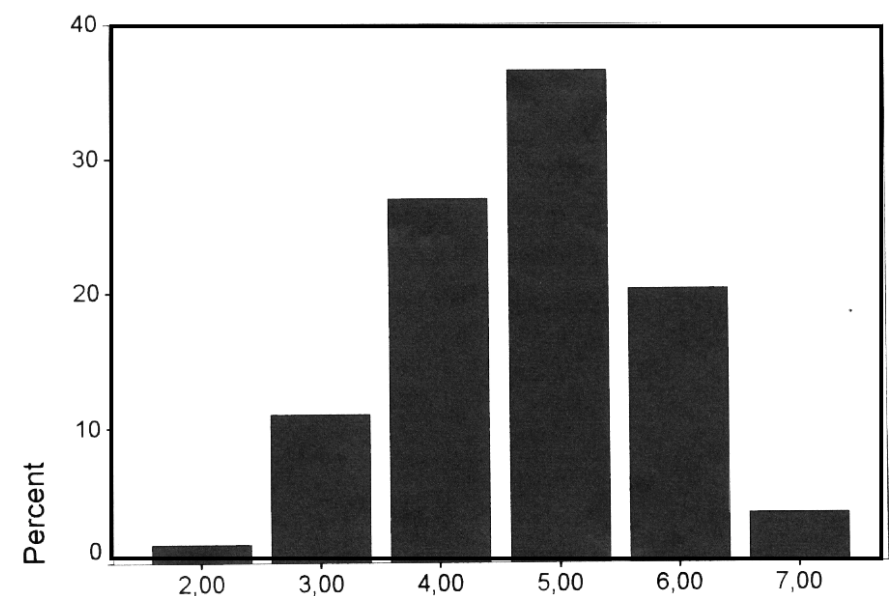

health index

A bell-shaped distribution was seen, with few individuals at the extremes and no indication of a bimodal or trimodal distribution.

Analysis of variance was calculated between the health practices index and psychosocial factors.

Table 2: ANOVA between psychological and sociodemographics variables and the Health Practices Index

\begin{tabular}{|l|l|}
\hline Variables & F \\
\hline Age & .983 \\
\hline Religion (ZCo/Apostolic/African versus Christian) & .458 \\
\hline Varried versus single & .984 \\
\hline Natural wersus social sciences students & 1.819 \\
\hline Having children versus no children & .476 \\
\hline SES & 1.599 \\
\hline Formal educ ation of father & 1.031 \\
\hline Formal educ ation of mother & $2.411^{*}$ \\
\hline Income & 1.221 \\
\hline Subjective he alth & -.102 \\
\hline Subjective well-being & 1.484 \\
\hline Internal & $2.103^{*}$ \\
\hline Powerful & 1.683 \\
\hline Chance & 1.207 \\
\hline Health Locus of Control (total) & $1.997^{*}$ \\
\hline Health walue & .863 \\
\hline Beliefs of the importance of health behaviour & 1.066 \\
\hline Worse health status & $2.287^{*}$ \\
\hline
\end{tabular}

Among the sociodemographic variables none of the factors was associated with the health practices index except for the formal education of the mother. Regarding psychological factors the internal locus of control and also the total Health related locus of control measure was positively associated with the health practices index. Moreover, worse health status (more frequent doctor visits, more often medicines prescribed by a doctor and more often bought medicines from a shop in the past 4 weeks) was also associated with the health practices index.

The item-correlations between non-smoking, nondrinking and eating pattern are shown in Table 3.

Table 3: Inter-item correlations between nosmoking, non-drinking and eating pattern

\begin{tabular}{|c|c|c|c|c|c|c|c|c|}
\hline Healthy behaviour & 1 & 2 & 3 & 4 & 5 & 6 & 77 & 8 \\
\hline 1. Non-tobacco use & 1.000 & & & & & & & \\
\hline 2. No/Limited alcohol & $.451^{\# *}$ & 1.000 & & & & & & \\
\hline 3. Limited red meat & $.099^{ \pm+1}$ & $.073^{*}$ & 1.000 & & & & & \\
\hline $\begin{array}{l}\text { 4. Avoid fat and } \\
\text { cholesterol }\end{array}$ & $.154^{+\ldots+}$ & $.097 *$ & -.042 & 1.000 & & & & \\
\hline 5. Limited salt & -.016 & -.037 & -.042 & $.077^{*}$ & 1.000 & & & \\
\hline 6. Daily fruits & .059 & $.084^{*}$ & $-.104^{*+1}$ & $.107^{\text {t* }}$ & -.008 & 1.000 & & \\
\hline 7. Daily breakfast & -.027 & .046 & $-.106^{\text {th }}$ & 039 & -.015 & $.119^{ \pm+*}$ & 1.000 & \\
\hline $\begin{array}{l}\text { 8. No between-meal } \\
\text { snacks }\end{array}$ & $-.155^{\ldots+1}$ & $-.093^{*}$ & $.105^{* t}$ & -.035 & $-.109^{\#+}$ & $-.091^{*}$ & $-.080^{*}$ & 1.000 \\
\hline
\end{tabular}

Non-tobacco use was positively correlated with no/ limited alcohol use, avoiding fat and limited red meat, and it was negatively associated with "no between-meal snacks". No or limited alcohol use was associated with avoiding fat, daily fruits, and limited red meat, and negatively related with "no between-meal snacks". Limited red meat consumption was negatively related with daily breakfast and daily fruits but positively associated with "no between-meal snacks". Daily fruits was positively associated with daily breakfast and avoiding fat and cholesterol. Limited salt was only positively related to avoiding fat.

Inter-item correlations between other health behaviours (physical exercise, sleep time, never sunbath or uses of sunscreen, always wearing a seat belt, breast or testicle self-examination) were generally low, indicating considerable independence among health practices. This is corroborated by the 
Cronbach alpha estimates which were positive but low (.34).

Principal component analysis extracted 6 factors explaning $58 \%$ of the variance. Here the different factors seems also to indicate the considerable independence among health practices (see Table 4).

Table 4: Factor structure of the Health Practices Index

\begin{tabular}{|c|c|c|c|c|c|c|}
\hline Healthy behaviour & 1 & 2 & 3 & 4 & 5 & 6 \\
\hline 1. Non-tobacco use & .502 & & & & & \\
\hline $\begin{array}{l}\text { 2. Alcohol consumption: very occasional or non- } \\
\text { drinker }\end{array}$ & & & & & & .411 \\
\hline 3. Physical exercise in past 2 weeks & & & & .612 & & \\
\hline 4. Sleep time ( 7 to 8 hours) & & & -.543 & & & \\
\hline 5. Never sunbathes or uses sunscreen & .372 & & & & & \\
\hline G. Brushes teeth once or more per day & & & & & -.596 & \\
\hline 7. Limited red meat & & .532 & & & & \\
\hline $\begin{array}{l}\text { 8. Awoid eating foods that contain fat and } \\
\text { cholesterol }\end{array}$ & & & .607 & & & \\
\hline 9. Limited salt & & -.576 & & & & \\
\hline 10. Fruits at least once a day & .522 & & & & & \\
\hline 11. Breakfast almost every day & & & & & & .691 \\
\hline 12. No between-meal snacks & & .509 & & & & \\
\hline 13. Wearing a seat belt & .602 & & & & & \\
\hline 14. Breast self-examination & & & & & & -.501 \\
\hline
\end{tabular}

\section{DISCUSSION}

\section{Prevalence of healthy practices}

The use of absolute criteria for classifying health practices resulted in a wide variation in the prevalence of each positive practice (cf. also Steptoe et al. 1994:338). For example, more than $70 \%$ of the participants scored positively for the items concerning brushing teeth, tobacco use, limiting alcohol consumption, limiting red meat, and protection from the sun, while fewer than $40 \%$ fulfilled criteria for breast or testicle self-examination, no inbetween meal snacks and fruit at least once a day, and always wearing seat belts. The distribution of the health practices index depends on the behaviours included, and a different set of practices (such as safer sex practices, dental or blood pressure check-ups) might have resulted in a different pattern (ibid.:339). Several health practices such as eating fruits daily, consistent seat belt use and testicle self-examination are practiced by only a minority of the sample, which may raise concern and should be further investigated. Although rare, testicular cancer is the most common cancer in men aged 20-35, and chemotherapy is effective if the cancer is diagnosed early (Steptoe \& Wardle, 1996:63). In comparision with European samples, students in this sample had a much higher rate of non-smokers $(80 \%)$ (as compared to Britain $69.2 \%$ ), and limited alcohol consumption (78\%) (as compared to Britain 67.1\%). However, this sample had much lower recommended fruit consumption (29\%) as compared to British students (53.1\%) (Norman, Bennett, Smith \& Murphy, 1998:174). Steptoe and Wardle (1992:490) found among European university students that the proportion of non-smokers ranged across countries, from 54.8 to 84.6 percent for men and 59.3 to 87.6 percent for women. Various practices included in the index should not be considered as having equal importance to health. For instance, not smoking can be seen as much more important than having breakfast everyday (Steptoe et al. 1994:339).

\section{Sociodemographic variables}

This study found that on average the women's behaviour was more healthy than that of the men. In accordance with a study among European university students (Steptoe et al. 1994:339) the total mean health practices index score was higher for women than for men, reflecting the general finding that women show healthier behaviours than men across a wide range of activities. Despite this difference, the distribution of the health practices index was similar in the two sexes. The assumption that with rising socioeconomic status healthy lifestyle may deteriorate was not confirmed. Interesting is, however, that formal education of the mother of the participant was positively related with the health behaviour score. This is an important finding for health promotion programmes.

\section{Psychosocial correlates}

Results of analysis of the health-related locus of control scales presented a mixed pattern. The only robust effect was that participants with a more 
healthy lifestyle had stronger internal locus of control than others did. This finding is in line with findings with a health behaviour measure, which had been used with a representative population sample in Britain (Norman et al. 1998:171). Moreover, worse health status (more frequent doctor visits, more often medicines prescribed by a doctor and more often bought medicines from a shop in the past 4 weeks) was also associated with the health practices index. This seems to indicate that healthy practices lead to an improved health status.

\section{Limitations}

Limitations of the study are that such health behaviours like safer sex and blood pressure or dental check-ups have not been included. It should also be mentioned that this study only looked at psychosocial factors as determinants of health-conscious and unhealthy practices and disregarded macroeconomic conditions, the sociocultural context, family habits, and personality factors (see Steptoe et al. 1994). The health practices index used here assessed more health hazard/health risk appraisal or health-protecting (preventive) behaviours based on a risk-reduction model rather than on a health-enhancement model such as in the HealthPromoting Lifestyle Profile (Walker et al. 1981).

\section{Acknowledgement}

Andrew Steptoe is thanked for the research instrument and the University of the North for financially supporting the study.

\section{REFERENCES}

Bradshaw, D; Bourne, DE; Schneider, M \& Sayed, R 1995: Mortality patterns of chronic diseases of life style in South Africa (In: Furie, J \& Steyn, K eds. 1995: Chronic diseases of life style in South Africa. Cape Town: MRC Technical Reports, pp. 5-36).

Edwards, DJA 1992: The challenge of hypertension to South African health psychology: 1. The potential con- tribution of educational, cognitive and behavioural strategies to prevention and treatment. South African Journal of Psychology, 22:105-116.

Forjuoh, SN; Zwi, AB \& Mock, CN 1998: Injury control in Africa: getting governments to do more. Tropical Medicine and International Health, 3:349-356.

Lau, RR \& Ware, JE jr. 1981: Refinements in the measurement of health-specific locus-of-control beliefs. Medical Care, 19:1147-1158.

Levitt, NS; Zwarenstein, MF; Doepfmer, S; Bawa, AA; Katzenellenbogen, J \& Bradshaw D 1996: Public sector primary care of diabetics - a record review of quality care in Cape Town. South African Medical Journal, 86:1013-20.

Norman, P; Bennett, P; Smith, C \& Murphy, S 1998: Health locus of control and health behaviour. Journal of Health Psychology, 3:171-180.

Peltzer, K 1995: Psychology and health in African cultures. Frankfurt/M.: IKO Verlag.

Seedat, YK; Seedat, MA \& Hackland, DB 1982: Prevalence of hypertension in urban and rural Zulu. Journal of Epidemiology and Community Health, 36:256-261.

Steptoe, A \& Wardle, J 1992: Cognitive predictors of health behaviour in contrasting regions of Europe. British Journal of Clinical Psychology, 31:485-502.

Steptoe, A \& Wardle, J 1996: The European health and behaviour survey: the development of an international study in health psychology. Psychology and Health, 11:49-73.

Steptoe, A; Wardle, J; Vinck, J; Tuomisto, M; Holte, A $\&$ Wichstrøm, L 1994: Personality and attitudinal correlates of healthy and unhealthy lifestyles in young adults. Psychology and Health, 9:331-343.

Steyn, K; Fourie, J; Lombard, C; Katzenellenbogen, J; 
Bourne, L \& Jooste P 1996: Hypertension in the black community of the Cape Peninsula, South Africa. East African Medical Journal, 73:758-763.

Walker, ARP 1995: Epidemiology and health implications of obesity in Southern Africa. (In: Furie, J \& Steyn, K eds. 1995: Chronic diseases of life style in South Africa. Cape Town: MRC Technical Reports, pp. 73-86).

Walker, SN; Sechrist, KR \& Pender, NJ 1981: The healthpromoting lifestyle profile: development and psychometric characteristics. Nursing Research, 36:76-81.

Wallston, KA; Wallston, BS \& DeVellis, R 1978: Development of the multi-dimensional health locus of control. Health Education Monographs, 6:160-170.

Yach, D 1996: Tobacco in Africa. World Health Forum, 17:29-36. 